\title{
Multiplikasi Anggrek Hitam ( Coelogyne pandurata Lindl ) Pada Media Murashige Skoog (Ms) Dengan Penambahan Ekstrak Pisang Ambon dan Benzyl Amino Purin (BAP)
}

\author{
Nurfadilah ${ }^{1}$, Mukarlina ${ }^{1}$, Elvi Rusmiyanto P.W ${ }^{1}$ \\ ${ }^{1}$ Program Studi Biologi, Fakultas MIPA, Universitas Tanjungpura, Jl. Prof. Dr. H. Hadari Nawawi, Pontianak, \\ Email Korespondensi: nurfadilah67193@gmail.com
}

\begin{abstract}
Black orchids (Coelogyne pandurata Lindl.) are epiphytic and endemic in Borneo. Habitat damage and over exploitation by the society can cause black orchids to be threatened with extinction. For this reason, alternative ways to increase black orchids are needed through tissue culture techniques with the addition of ambon banana extract and Benzyl Amino Purine BAP. The aim of this study was to determine the effect of ambon banana extract and BAP on the multiplication of black orchids. This research was conducted for 3 months from January to March 2018 at Pontianak Aloe Vera Center (AVC) Tissue Culture Laboratory. This study uses a Completely Randomized Design (CRD) with two factors. The first factor was ambon banana extract $(0 \% ; 2,5 \% ; 5 \% ; 7,5 \%$ and $10 \%)$ and the second factors BAP $\left(0 \mathrm{M} ; 10^{-7} \mathrm{M} ; 10^{-6} \mathrm{M} ; 5 \times 10^{-6} \mathrm{M}\right)$ with 3 replications, each of which obtained 60 trial unit. The results showed that the ambon banana extract had a significant effect on the time of budding, number of buds and number of leaves. The concentration of ambon banana extract $2,5 \%$ resulted in the fastest budding time appearing on the $11,33^{\text {th }}$ day, the number of buds was 8,33 tillers, and the number of leaves was 17,67 strands.
\end{abstract}

Keywords: BAP, Coelogyne pandurata, Banana ambon extract, Multiplication

\section{PENDAHULUAN}

Tanaman anggrek (Orchidaceae) meliputi 25.00030.000 spesies dan merupakan $10 \%$ dari jumlah tanaman berbunga di dunia. Anggrek hitam (Coelogyne pandurata Lindl.) merupakan anggrek endemik yang hanya ditemukan di beberapa kawasan terbatas di Kalimantan. Selain kelangkaannya, anggrek hitam memiliki nilai ekonomi yang tinggi (Lestari \& Deswiniyanti, 2015).

Anggrek hitam merupakan jenis anggrek yang dilindungi keberadaannya. Perubahan atau rusaknya habitat tumbuh akibat penebangan dan konversi lahan yang menjadi ancaman terhadap kelestarian anggrek hitam. Kegiatan pengeksploitasian anggrek dari alam yang dilakukan secara berlebihan dan kebakaran hutan yang menyebabkan kerusakan habitat alami dapat mengakibatkan kepunahan bila tidak diimbangi dengan usaha konservasi (Silalahi et al., 2008).

Teknik multiplikasi tunas anggrek secara in vitro merupakan salah satu usaha mencegah kepunahan jenis anggrek hitam. Teknik multiplikasi dapat menyediakan anakan baru anggrek alam secara cepat dengan kualitas dan kuantitas yang baik. Multiplikasi tunas anggrek secara in vitro dengan media buatan yang sesuai merupakan solusi yang dapat mengatasi masalah dalam perbanyakan dan budidaya tanaman (Wattimena,1992).

Zat pengatur tumbuh diperoleh dari senyawa organik maupun sintetik. Salah satu sumber zat pengatur tumbuh organik adalah ekstrak pisang ambon. Hasil penelitian Arditti \& Ernts (1992) menunjukkan bahwa buah pisang mengandung hormon tumbuh seperti auksin dan giberelin serta nutrisi penting sebagai zat pengatur tumbuh eksogen.

Ekstrak pisang dalam kultur jaringan, menurut Untari dan Puspitaningtyas (2006) umumnya digunakan sebanyak 150-200 g/L. Ekstrak pisang yang ditambahkan pada media kultur jaringan dapat merangsang pembelahan sel dan mendorong diferensiasi sel, sehingga tunas dapat tumbuh dengan baik. Kandungan ekstrak pisang ambon juga mengandung unsur-unsur kalium (K), fosfor $(\mathrm{P})$ dan besi $(\mathrm{Fe})$ dan sehingga memberikan pengaruh positif terhadap pertumbuhan tunas.

Penggunaan zat pengatur tumbuh sintetik juga dapat dikombinasikan dengan zat pengatur tumbuh organik. Salah satu zat pengatur tumbuh yang dapat 
digunakan adalah Benzyl Amino Purin (BAP). BAP termasuk zat pengatur tumbuh golongan sitokinin yang berfungsi meningkatkan pembelahan sel, proliferasi pucuk dan morfogenesis pucuk (Zulkarnain, 2009). Kombinasi ekstrak pisang ambon dan BAP diharapkan dapat menghasilkan multiplikasi tunas anggrek hitam lebih baik.

\section{BAHAN DAN METODE}

\section{Waktu dan Tempat Penelitian}

Penelitian dilaksanakan selama 3 bulan (JanuariMaret 2018) di Unit Pelaksana Teknis Daerah (UPTD) Agribisnis Aloe Vera Center (AVC), Dinas Pertanian Perikanan dan Kehutanan Kota Pontianak, Kecamatan Pontianak Utara Kota Pontianak.

\section{Rancangan Percobaan}

Rancangan percobaan yang digunakan adalah Rancangan Acak Lengkap (RAL) dengan dua faktor, faktor pertama ekstrak pisang ambon (P) dengan konsentrasi 0 (P1), 2,5\% (P2), 5\% (P3), $7,5 \%(\mathrm{P} 4), 10 \%(\mathrm{P} 5)$ dan faktor kedua BAP (B) dengan konsentrasi 0 (B1), $10^{-7} \mathrm{M}(\mathrm{B} 2), 10^{-6} \mathrm{M}$ (B3), $5 \times 10^{-6} \mathrm{M}$ (B4). Kedua faktor dikombinasikan sehingga diperoleh 20 perlakuan. Setiap perlakuan diulang 3 kali sehingga diperoleh 60 unit percobaan.

\section{Bahan}

Bahan-bahan yang digunakan adalah agar, akuades, alkohol $70 \%$, plantlet anggrek hitam, arang aktif, ekstrak pisang ambon, gula pasir, Asam Klorida (HCl), larutan stok, Benzyl Amino Purin (BAP), media Murashige Skoog (MS) dan Natrium Hidroksida $(\mathrm{NaOH})$.

\section{Prosedur Kerja \\ Pembuatan Larutan Ekstrak Pisang Ambon dan BAP}

Pisang ambon yang digunakan adalah pisang yang masak pohon ditandai dengan daging buah bertekstur lembut. Pisang ambon sebanyak $500 \mathrm{~g}$ dihaluskan dengan blender menggunakan air secukupnya, kemudian dimasukkan ke dalam botol steril dan ditutup.

Stok BAP dibuat dalam konsentrasi $10^{-3} \mathrm{M}$ sebanyak $100 \mathrm{ml}$. Larutan dipindahkan ke dalam botol kaca dan ditutup rapat serta diberi label, selanjutnya disimpan dalam lemari es sebelum digunakan.

\section{Pembuatan Larutan Stok Hara}

Pembuatan larutan stok makro, mikro dan vitamin dengan cara menimbang bahan-bahan kimia sesuai komposisi media, kemudian diencerkan dengan akuades sebanyak $100 \mathrm{ml}$. Larutan tersebut diaduk sampai homogen dengan magnetic stirrer. Selanjutnya larutan dimasukkan dalam botol yang telah diberi label.

\section{Multiplikasi Anggrek Hitam}

Kegiatan multiplikasi dilakukan di dalam LAFC. Eksplan yang digunakan yaitu tunas anggrek hitam yang telah dimultiplikasi. Eksplan yang berada di dalam botol kultur dikeluarkan dari botol kultur dan diletakkan pada cawan petri yang berisi kertas saring, tunas-tunas dipisahkan, kemudian dimasukkan pada botol media. Setiap botol ditanam dua tunas anggrek hitam. Botol-botol kultur yang berisi eksplan diberi label, kemudian dibawa ke ruang inkubasi.

\section{Inkubasi Kultur Anggrek Hitam}

Botol yang telah ditanami eksplan anggrek hitam diberi label yang memuat informasi jenis eksplan, botol-botol kultur tersebut disusun di rak kultur yang ada di ruang inkubasi. Selama masa inkubasi dilakukan pengamatan terhadap kultur setiap minggu selama 12 minggu.

\section{Parameter Pengamatan}

Parameter pengamatan yang digunakan pada penelitian ini, yaitu waktu Muncul Tunas (hari), Jumlah tunas, Jumlah daun (helai).

\section{Analisis Data}

Data pengamatan dianalisis menggunakan Analysis of Varians (ANOVA) dua faktor dan jika terdapat pengaruh nyata, pengujian dilanjutkan dengan uji Duncan taraf nyata 5\% (Pramesti, 2011).

\section{Hasil}

\section{Waktu Muncul Tunas}

Hasil analisis ANAVA menunjukkan perlakuan ekstrak pisang ambon berpengaruh nyata terhadap waktu muncul tunas anggrek hitam $\left(\mathrm{F}_{19,40}=6,847 p\right.$ $=0,006$; ANAVA). Sedangkan perlakuan BAP $\left(\mathrm{F}_{19,40}=0,772 p=0,541 ;\right.$ ANAVA $)$ dan kombinasi $\left(\mathrm{F}_{19,40}=0,926 p=0,533\right.$; ANAVA $)$ tidak berpengaruh nyata terhadap waktu muncul tunas anggrek hitam. 
Tabel 1 Rerata waktu muncul tunas (hari) anggrek hitam dengan perlakuan ekstrak pisang ambon

\begin{tabular}{cc}
\hline $\begin{array}{c}\text { Ekstrak Pisang } \\
\text { Ambon }(\%)\end{array}$ & $\begin{array}{c}\text { Waktu Muncul Tunas } \\
(\text { Hari })\end{array}$ \\
\hline 0 & $38,00^{\mathrm{a}}$ \\
2,5 & $\mathbf{1 1 , 3 3}^{\mathrm{b}}$ \\
5 & $14,00^{\mathrm{b}}$ \\
7,5 & $15,33^{\mathrm{b}}$ \\
10 & $23,67^{\mathrm{a}}$
\end{tabular}

Keterangan: Angka yang diikuti oleh huruf yang sama menunjukkan hasil yang tidak berbeda nyata

Hasil analisis menunjukkan bahwa perlakuan ekstrak pisang ambon pada konsentrasi 2,5, 5 dan $7,5 \%$ berbeda nyata dengan kontrol dan konsentrasi $10 \%$ (Tabel 1). Perlakuan ekstrak pisang ambon 2,5\% menghasilkan pertumbuhan tunas tercepat yaitu hari ke 11,33 (Tabel 1).

Tabel 2 Rerata waktu muncul tunas (hari) anggrek hitam dengan perlakuan BAP

\begin{tabular}{cc}
\hline BAP $(\mathrm{M})$ & $\begin{array}{c}\text { Waktu Muncul Tunas } \\
(\text { Hari) }\end{array}$ \\
\hline 0 & $38,00^{\mathrm{a}}$ \\
$10^{-7}$ & $42,33^{\mathrm{a}}$ \\
$10^{-6}$ & $31,00^{\mathrm{a}}$ \\
$5 \times 10^{-6}$ & $\mathbf{2 9 , 3 3}^{\mathrm{a}}$ \\
\hline
\end{tabular}

Keterangan: Angka yang diikuti oleh huruf yang sama menunjukkan hasil yang tidak berbeda nyata

Berdasarkan hasil pengamatan perlakuan BAP $5 \times 10^{-6} \mathrm{M}$ menunjukkan waktu muncul tunas tercepat yaitu hari ke 29,33 (Tabel 2).

Tabel 3 Rerata waktu muncul tunas (hari) anggrek hitam dengan perlakuan kombinasi ekstrak pisang ambon dan BAP

\begin{tabular}{ccccc}
\hline \multirow{2}{*}{$\begin{array}{c}\text { BAP } \\
(\mathrm{M})\end{array}$} & \multicolumn{4}{c}{ Ekstrak Pisang Ambon (\%) } \\
\cline { 2 - 5 } & 2,5 & 5 & 7,5 & 10 \\
\hline $10^{-7}$ & $\mathbf{2 1 , 0 0}$ & $23,33^{\mathrm{a}}$ & $24,67^{\mathrm{a}}$ & $32,00^{\mathrm{a}}$ \\
$10^{-6}$ & $22,00^{\mathrm{a}}$ & $26,00^{\mathrm{a}}$ & $31,67^{\mathrm{a}}$ & $37,67^{\mathrm{a}}$ \\
$5 \times 10^{-}$ & $27,33^{\mathrm{a}}$ & $31,67^{\mathrm{a}}$ & $33,33^{\mathrm{a}}$ & $39,00^{\mathrm{a}}$ \\
6 & & & & \\
\hline
\end{tabular}

Keterangan: Angka yang diikuti oleh huruf yang sama menunjukkan hasil yang tidak berbeda nyata

Waktu muncul tunas tercepat diperoleh pada perlakuan kombinasi BAP $10^{-7} \mathrm{M}$ dan ekstrak pisang ambon 2,5\% yaitu hari ke 21 (Tabel 3).

\section{Jumlah Tunas}

Hasil analisis ANAVA menunjukkan perlakuan ekstrak pisang ambon $\left(\mathrm{F}_{19,40}=5,970 p=0,010\right.$; ANAVA $)$ dan perlakuan BAP $\left(\mathrm{F}_{19,40}=3,389 p=\right.$ 0,027; ANAVA) serta perlakuan kombinasi $\left(\mathrm{F}_{19,40}=\right.$ $2,610 p=0,024$; ANAVA) memberikan pengaruh nyata terhadap jumlah tunas anggrek hitam.
Tabel 4 Rerata jumlah tunas anggrek hitam dengan perlakuan ekstrak pisang ambon (90 hst)

\begin{tabular}{cc}
\hline $\begin{array}{c}\text { Ekstrak Pisang } \\
\text { Ambon }(\%)\end{array}$ & Jumlah Tunas \\
\hline 0 & $1,33^{\mathrm{a}}$ \\
2,5 & $\mathbf{8 , 3 3}^{\mathrm{d}}$ \\
5 & $6,00^{\mathrm{cd}}$ \\
7,5 & $6,33^{\mathrm{cd}}$ \\
10 & $3,67^{\mathrm{abc}}$ \\
\hline
\end{tabular}

Keterangan: Angka yang diikuti oleh huruf yang sama menunjukkan hasil yang tidak berbeda nyata

Hasil analisis diperoleh bahwa perlakuan ekstrak pisang ambon 2,5\% berbeda nyata dengan kontrol tetapi tidak berbeda nyata dengan konsentrasi $5 \%$ dan $7,5 \%$ (Tabel 4). Konsentrasi ekstrak pisang ambon 2,5\% menunjukkan jumlah tunas terbanyak yaitu 8,33 tunas (Tabel 4).

Tabel 5 Rerata jumlah tunas anggrek hitam dengan perlakuan BAP (90 hst)

\begin{tabular}{cc}
\hline BAP $(\mathrm{M})$ & Jumlah Tunas \\
\hline 0 & $1,33^{\mathrm{a}}$ \\
$10^{-7}$ & $2,67^{\mathrm{abc}}$ \\
$10^{-6}$ & $1,33^{\mathrm{a}}$ \\
$5 \times 10^{-6}$ & $\mathbf{3 , 3 3}^{\text {abc }}$
\end{tabular}

Keterangan: Angka yang diikuti oleh huruf yang sama menunjukkan hasil yang tidak berbeda nyata

Semua perlakuan BAP tidak berbeda nyata dengan kontrol. Jumlah tunas dengan konsentrasi $5 \times 10^{-6} \mathrm{M}$ menghasilkan jumlah tunas paling banyak yaitu 3,33 tunas (Tabel 5).

Tabel 6 Rerata jumlah tunas anggrek hitam dengan perlakuan kombinasi ekstrak pisang ambon dan BAP (90 hst)

\begin{tabular}{ccccc}
\hline \multirow{3}{*}{$\begin{array}{c}\text { BAP } \\
(\mathrm{M})\end{array}$} & \multicolumn{4}{c}{ Ekstrak Pisang Ambon (\%) } \\
\cline { 2 - 5 } & 2,5 & 5 & 7,5 & 10 \\
\hline $10^{-7}$ & $6,00^{\text {cd }}$ & $5,00^{\text {abcd }}$ & $5,67^{\text {bcd }}$ & $4,33^{\text {abcd }}$ \\
$10^{-6}$ & $\mathbf{6 , 3 3}^{\text {cd }}$ & $5,00^{\text {abcd }}$ & $5,00^{\text {abcd }}$ & $3,00^{\text {abc }}$ \\
$5 \times 10^{-}$ & $3,33^{\text {abc }}$ & $3,33^{\text {abc }}$ & $3,33^{\text {abc }}$ & $1,67^{\text {bc }}$ \\
6 & & & &
\end{tabular}

Keterangan: Angka yang diikuti oleh huruf yang sama menunjukkan hasil yang tidak berbeda nyata

Hasil analisis menunjukkan bahwa kombinasi pada konsentrasi BAP $10^{-6} \mathrm{M}$ dan ekstrak pisang ambon 2,5\% menunjukkan hasil berbeda nyata dengan kontrol, tetapi tidak berbeda nyata dengan konsentrasi BAP $10^{-7} \mathrm{M}$ dan ekstrak pisang ambon $2,5 \%$ dan $10^{-7} \mathrm{M}$ BAP $10^{-7} \mathrm{M}$ dan ekstrak pisang ambon $7,5 \%$. Berdasarkan hasil pengamatan jumlah tunas pada perlakuan kombinasi dengan konsentrasi $10^{-6} \mathrm{M}$ BAP dan 2,5\% ekstrak pisang ambon menghasilkan tunas terbanyak yaitu 6,33 tunas (Tabel 6). 


\section{Jumlah Daun}

Hasil analisis ANAVA menunjukkan perlakuan ekstrak pisang ambon $\left(\mathrm{F}_{19,40}=8,875 p=0,003\right.$; ANAVA $)$ dan perlakuan BAP $\left(\mathrm{F}_{19,40}=6,944 p=\right.$ 0,013; ANAVA) serta perlakuan kombinasi $\left(\mathrm{F}_{19,40}=\right.$ $2,858 p=0,015$; ANAVA) memberikan pengaruh nyata terhadap jumlah daun anggrek hitam.

Tabel 7 Rerata jumlah daun anggrek hitam dengan perlakuan ekstrak pisang ambon (90 hst)

\begin{tabular}{cc}
\hline $\begin{array}{c}\text { Ekstrak Pisang } \\
\text { Ambon }(\%)\end{array}$ & Jumlah Daun \\
\hline 0 & $3,67^{\mathrm{a}}$ \\
2,5 & $\mathbf{1 7 , 6 7}^{\mathrm{d}}$ \\
5 & $14,00^{\mathrm{cd}}$ \\
7,5 & $12,67^{\mathrm{bcd}}$ \\
10 & $8,33^{\mathrm{abc}}$ \\
\hline
\end{tabular}

Keterangan: Angka yang diikuti oleh huruf yang sama menunjukkan hasil yang tidak berbeda nyata

Hasil analisis menunjukkan bahwa perlakuan ekstrak pisang ambon 2,5\% menunjukkan hasil berbeda nyata dengan kontrol dan konsentrasi $10 \%$, tetapi tidak berbeda nyata dengan konsentrasi $5 \%$ dan 7,5\% (Tabel 7). Jumlah daun pada perlakuan ekstrak pisang ambon 2,5\% menunjukkan jumlah daun paling banyak yaitu 17,67 helai (Tabel 7).

Tabel 8 Rerata jumlah daun anggrek hitam dengan perlakuan BAP (90 hst)

\begin{tabular}{cc}
\hline BAP $(\mathrm{M})$ & Jumlah Daun \\
\hline 0 & $3,67^{\mathrm{a}}$ \\
$10^{-7}$ & $7,33^{\mathrm{abc}}$ \\
$10^{-6}$ & $8,00^{\mathrm{abc}}$ \\
$5 \times 10^{-6}$ & $8,33^{\mathrm{abc}}$ \\
\hline
\end{tabular}

Keterangan: Angka yang diikuti oleh huruf yang sama menunjukkan hasil yang tidak berbeda nyata

Semua perlakuan BAP tidak berbeda nyata dengan kontrol. Jumlah tunas terhadap Perlakuan tunggal BAP dengan konsentrasi $5 \times 10^{-6} \mathrm{M}$ menghasilkan jumlah daun paling banyak yaitu 8,33 helai (Tabel 8).

Perlakuan kombinasi dengan konsentrasi BAP 10${ }^{6} \mathrm{M}$ dan ekstrak pisang ambon $2,5 \%$ berbeda nyata dengan kontrol dan BAP $10^{-6} \mathrm{M}$ dan ekstrak pisang ambon $5 \%$, tetapi tidak berbeda nyata dengan konsentrasi lainnya. Berdasarkan hasil pengamatan jumlah tunas pada perlakuan kombinas konsentrasi BAP $10^{-6} \mathrm{M}$ dan ekstrak pisang ambon 2,5\% menghasilkan daun terbanyak yaitu 6-7 helai (Tabel 9).
Tabel 9 Rerata jumlah daun anggrek hitam dengan perlakuan kombinasi ekstrak pisang ambon dan BAP (90 hst)

\begin{tabular}{ccccc}
\hline \multirow{2}{*}{$\begin{array}{c}\text { BAP } \\
(\mathrm{M})\end{array}$} & \multicolumn{4}{c}{ Ekstrak Pisang Ambon (\%) } \\
\cline { 2 - 5 } & 2,5 & 5 & 7,5 & 10 \\
\hline $10^{-7}$ & $12,33^{\text {bcd }}$ & $11,33^{\text {abcd }}$ & $11,33^{\text {abcd }}$ & $8,00^{\text {abc }}$ \\
$10^{-6}$ & $\mathbf{1 5 , 3 3}^{\text {cd }}$ & $12,00^{\text {abcd }}$ & $10,00^{\text {abcd }}$ & $4,67^{\text {ab }}$ \\
$5 \times 10^{-6}$ & $9,33^{\text {abcd }}$ & $10,00^{\text {abcd }}$ & $13,33^{\text {cd }}$ & $9,33^{\text {abcd }}$ \\
\hline
\end{tabular}

Keterangan: Angka yang diikuti oleh huruf yang sama menunjukkan hasil yang tidak berbeda nyata

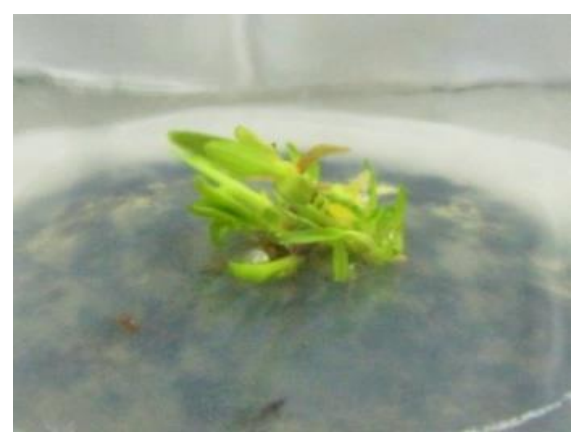

Gambar 1. Hasil Multiplikasi Tunas Anggrek hitam pada konsentrasi ekstrak pisang ambon 2,5\%.

\section{Pembahasan}

Berdasarkan hasil penelitian diketahui bahwa perlakuan ekstrak pisang ambon dengan konsentrasi $2,5 \%$ (Gambar 1) menghasilkan rata-rata nilai terbaik terhadap waktu muncul tunas, jumlah tunas dan jumlah daun (Tabel 1, tabel 4, dan tabel 7). Zat pengatur tumbuh yang terkandung dalam ekstrak pisang ambon 2,5\% sudah mampu untuk memicu pembelahan dan pemanjangan sel pada tunas anggrek hitam sehingga mempercepat pertumbuhan tunas dan daun. Menurut Widiastoety \& Bahar (1995) ekstrak pisang ambon yang ditambahkan pada media kultur jaringan mengandung auksin dan sitokinin sehingga dapat merangsang pembelahan sel dan mendorong diferensiasi sel, yang berguna untuk memacu multiplikasi sel. Arditti \& Ernst (1992) menambahkan bahwa auksin dapat memacu morfogenesis dan menginisiasi terbentuknya tunas lebih cepat, sedangkan giberalin menginduksi tumbuhnya tunas yang dorman. Penelitian Kasutjianingati \& Irawan (2013) menunjukkan hasil bahwa ekstrak pisang ambon dapat memberikan pengaruh yang baik terhadap parameter tinggi tanaman, jumlah akar, panjang akar, panjang daun, dan berat basah plantlet kultur jaringan anggrek Dendrobium. 
Berdasarkan hasil penelitian dapat diamati bahwa pembentukan tunas anggrek hitam diawali dengan adanya pembengkakan pada pangkal primordia tunas. Pembengkakan pada pangkal primordia tunas disebabkan oleh membesarnya sel-sel karena adanya zat pengatur tumbuh dalam ekstrak pisang ambon. Arditti \& Ernst (1992) menyatakan bahwa ekstrak pisang ambon mengandung hormon auksin dan giberelin yang dapat memacu pemanjangan dan pembesaran sel.

Penambahan ekstrak pisang ambon tidak hanya sebagai sumber zat pengatur tumbuh tetapi juga sebagai sumber energi, unsur hara makro dan mikro. Pertumbuhan daun dan tunas didukung oleh tercukupinya sumber energi yaitu glukosa yang terdapat pada pisang ambon. Menurut Pramesyanti (1999) ekstrak pisang ambon mengandung kadar glukosa paling tinggi diantara jenis pisang lainnya. Glukosa sebagai bahan dasar respirasi dapat menghasilkan energi yang digunakan untuk memacu pembelahan sel pada primordia tunas dan daun.

Ekstrak pisang ambon mengandung unsur hara makro dan mikro seperti $\mathrm{N}, \mathrm{K}, \mathrm{Mg}$ dan $\mathrm{Fe}$ (Pramesyanti, 1999). Menurut Lakitan (1996) bahwa unsur $\mathrm{N}$ mempercepat pertumbuhan tanaman, menambah tinggi tanaman dan merangsang jumlah daun serta anakan. Unsur $\mathrm{K}$ berperan sebagai aktivator dari berbagai enzim yang essensial dalam reaksi fotosintesis dan respirasi, sedangkan unsur $\mathrm{Mg}$ berfungsi mengatur penyaluran zat karbohidrat dalam tubuh tanaman dan umumnya Fe berfungsi mengaktifkan enzim dalam proses metabolisme tumbuhan.

Perlakuan ekstrak pisang ambon pada konsentrasi $10 \%$ menghasilkan waktu muncul tunas lebih lama, serta jumlah tunas dan daun yang lebih sedikit (Tabel 1, tabel 4, dan tabel 7). Kondisi ini disebabkan tidak terjadi perimbangan antara zat pengatur tumbuh eksogen dalam ekstrak pisang ambon $10 \%$ dengan zat pengatur tumbuh endogen sehingga memperlambat multiplikasi tunas anggrek hitam. Menurut Hendaryono dan Wijayani (1994) serta Santoso \& Nursandi, (2004) menyatakan bahwa zat pengatur tumbuh eksogen pada konsentrasi yang tidak berimbang dengan zat pengatur tumbuh endogen lebih bersifat menghambat pertumbuhan tunas in vitro. Jumlah zat pengatur tumbuh endogen dalam tanaman yang melebihi konsentrasi yang diperlukan dapat menghambat pertumbuhan tanaman.
George \& Sherrington (1984) menyatakan bahwa pertumbuhan dan perkembangan eksplan dipengaruhi oleh perimbangan antara zat pengatur tumbuh endogen dan eksogen. Berbeda dengan penelitian Muawanah (2005) yang memberikan hasil terbaik untuk jumlah tunas dan daun dengan penambahan ekstrak pisang ambon $10 \%$ pada media kultur anggrek Dendrobium canayo. Hal ini dapat disebabkan perbedaan jenis anggrek yang di multiplikasi memberikan respon yang berbeda terhadap sumber zat pengatur tumbuh organik yang sama yang ditambahkan pada media kultur. Wattimena (1988) menyatakan bahwa variasi respon terhadap pemberian zat pengatur tumbuh dipengaruhi oleh perbedaan jenis tanaman, fase pertumbuhan, kondisi fisiologis dan kemampuan tanaman merespon zat pengatur tumbuh.

Pemberian BAP dengan konsentrasi BAP $5 \times 10^{-6} \mathrm{M}$ menghasilkan pertumbuhan yang terbaik terhadap waktu muncul tunas, jumlah tunas dan jumlah daun anggrek hitam (Tabel 2, tabel 5 dan tabel 8). Diduga pada kondisi ini sudah tercapai perimbangan yang tepat antara BAP $5 \times 10^{-6} \mathrm{M}$ dengan auksin endogen pada tunas anggrek hitam. Bakar et, al. (2016) menyatakan bahwa konsentrasi sitokinin dan auksin dengan perimbangan yang tepat antara zat pengatur tumbuh eksogen dan endogen akan bekerja secara optimal untuk merangsang pembelahan sel menjadi lebih cepat. Perimbangan sitokinin dan auksin yang tidak sesuai akan menghambat pembelahan sel.

Secara keseluruhan diketahui bahwa perlakuan BAP pada semua konsentrasi menghasilkan waktu muncul tunas lebih lama, jumlah tunas dan jumlah daun yang lebih sedikit dibandingkan perlakuan ekstrak pisang ambon. Diduga perlakuan BAP yang ditambahkan dapat mengubah perimbangan sitokinin endogen sehingga konsentrasi sitokinin supra optimum. Hal ini diduga kandungan sitokinin endogen di dalam eksplan sudah mencukupi untuk pembentukan tunas sehingga sitokinin eksogen yang ditambahkan pada media kultur tidak dapat mempercepat waktu muncul tunas, jumlah tunas dan jumlah daun. Menurut Lakitan (1996), penambahan sitokinin eksogen secara berlebih dapat menyebabkan konsentrasi sitokinin eksogen dan endogen menjadi supra optimum sehingga menghambat proses pembelahan sel.

Kombinasi antara pisang ambon dan BAP pada konsentrasi $10^{-6} \mathrm{M}$ BAP dan 2,5\% ekstrak pisang ambon menghasilkan pertumbuhan terbaik terhadap waktu muncul tunas, jumlah tunas dan jumlah daun (Tabel 3, tabel 6 dan tabel 9). Perimbangan antara 
zat pengatur tumbuh pada konsentrasi ekstrak pisang ambon tunggal yang rendah $(2,5 \%)$ dan konsentrasi BAP tunggal yang relatif tinggi $\left(10^{-6} \mathrm{M}\right)$ dengan zat pengatur tumbuh endogen mampu mempercepat pertumbuhan tunas anggrek hitam. Basri dan Muslimin (2001) menyatakan bahwa efektifitas sitokinin maupun auksin eksogen tergantung pada konsentrasi zat pengatur tumbuh endogen yang ada pada jaringan. Allan (1991) menyatakan bahwa perimbangan konsentrasi yang tepat antara auksin dan sitokinin eksogen dan endogen diketahui dapat memacu mikropopagasi tanaman.

Semua perlakuan kombinasi menunjukkan rata-rata nilai yang lebih rendah untuk semua parameter pertumbuhan dibandingkan dengan perlakuan ekstrak pisang ambon 2,5\%. Kondisi ini diduga belum tercapainya perimbangan antara zat pengatur tumbuh dalam ekstrak pisang ambon dan BAP dengan zat pengatur tumbuh endogen yang terdapat dalam tunas anggrek hitam. Zulkarnain (2009) menyatakan bahwa penambahan zat pengatur tumbuh yang tidak sesuai cenderung menyebabkan terhambatnya regenerasi tunas. Hal ini sesuai dengan penelitian Basri \& Muslimin (2001) yaitu efektifitas sitokinin maupun auksin eksogen tergantung pada konsentrasi zat pengatur tumbuh endogen yang ada pada jaringan tanaman. Perimbangan zat pengatur tumbuh terutama auksin dan sitokinin sangat menentukan keberhasilan suatu kultur.

\section{DAFTAR PUSTAKA}

Allan, E, 1991, Plant Cell and Tissue Culture, Wiley Publisher, Singapore

Arditti, J. \& Ernst, R, 1992, Fundamentals of Orchid Biology, John Wiley and Sons, New York

Bakar, M, Mandang, J, Kojoh, D, \& Demmasabu, S, 2016, Penggunaan BAP dan Kinetin pada Induksi Tunas dari Protocorm Anggrek Dendrobium (Dendrobium Sp.) pada Kultur In Vitro, Jurnal UNSRAT, Fakultas Pertanian Universitas Sam Ratulangi Manado, Manado

Basri, Z, \& Muslimin, 2001, Pengaruh Sitokinin Terhadap Organogenesis Krisan Secara In Vitro, Jurnal Agroland, 164-170

George, EF \& Sherrington, PD, 1984, Plant Propagatin by Tissue Culture, Handbook and Directionary of Commersial Laboratories Exegetic Ltd, England
Hendaryono, DP \& Wijayani, A, 1994, Teknik Kultur Jaringan, Pengenalan dan Petunjuk Perbanyakan Tanaman Secara Vegetatif-Modern, Penerbit Kanisius, Yogyakarta

Kasutjianingati, Irawan, R, 2013, Media Alternative Perbanyakan In-Vitro Anggrek Bulan (Phalaenopsis amabilis), Jurnal Agroteknos, Politeknik Negeri. Jember, vol. 3, no. 3, hal. 184189

Lakitan, B, 1996, Dasar-Dasar Fisiologi Tumbuhan, PT. Radja Grafindo Persada, Jakarta

Lestari, NKD \& Deswiniyanti, NW, 2015, Perbanyakan Anggrek Hitam (Coelogyne pandurata Lindl.) dengan Media Organik dan Vacin Went secara In Vitro, Jurnal Virgin, vol. 1, no.1, hal. 1

Muawanah, G, 2005, Penggunaan Pupuk Hyponex, Ekstrak Tomat dan Ekstrak Pisang dalam Perbanyakan dan Perbesaran Planlet Anggrek Dendrobium (Dendrobium canayo) secara In Vitro, Skripsi, Program Studi Hortikultura, Fakultas Pertanian, Institut Pertanian Bogor, Bogor

Pramesti, G, 2011, SPSS 16,0 dalam Rancangan Percobaan, PT. Elex Media Komputindo, Jakarta

Pramesyanti, A, 1999, Pengaruh Bubur Buah Beberapa Kutivar Pisang terhadap Pertumbuhan Vegetatif Plantlet Dendrobium Kamiya's Pride $\mathrm{x}$ Dendrobium Rulita Beauty pada Medium Vacin dan Went Modifikasi. Skripsi FMIPA, Jurusan Biologi, Universitas Indonesia, Jakarta

Santoso, U \& Nursandi, F, 2004, Kultur Jaringan Tanaman, Penerbit Universitas Muhammadiyah Malang, Malang

Silalahi, M., J. Lumbangaol, \& Irni. 2008. The Effect of Adding Benzyl Amino Purine BAP and Naphtalene Acetic Acid NAA to The Growth of Black Orchid (Coelogyne pandurata Lindl). by Using In Vitro Technique. Prosiding Seminar Nasional Sains dan Teknologi-II 2008 Universitas Lampung, 17-18 November 2008.

Untari, R \& Puspitaningtyas, DM, 2006, Pengaruh Bahan Organik dan NAA terhadap Pertumbuhan Anggrek Hitam (Coelogyne pandurata Lindl.) dalam Kultur In Vitro, IPB, Bogor, Jurnal Biodiversitas, vol. 7, no. 3, hal. 344-348

Wattimena, GA, 1998, Zat Pengatur Tumbuh Tanaman, Departemen Pendidikan dan Kebudayaan Direktoral Jendral Pendidikan Tinggi Pusat Antar Universitas Bioteknologi, IPB, Bogor 
Protobiont (2018) Vol. 7 (3) : $47-53$

Wattimena, GA, 1992, Bioteknologi Tanaman, Laboratorium Kultur Jaringan, Dekdikbud Dirjen Pendidikan Tinggi, PAU Bioteknologi, IPB, Bogor

Widiastoety, DN \& Bahar, FH, 1995, Pengaruh Berbagai Sumber dan Kadar Karbohidrat Terhadap Pertumbuhan Anggrek Dendrobium, Jurnal Hortikultura, vol. 5, no. 5, hal. 76-80

Zulkarnain, 2009, Kultur Jaringan Tanaman, Bumi Aksara, Jakarta 